\title{
Transient increase in renal insulin-like growth factor binding proteins during initial kidney hypertrophy in experimental diabetes in rats
}

\author{
A.Flyvbjerg ${ }^{1}$, U. Kessler ${ }^{2}$, B.Dorka ${ }^{2}$, B. Funk ${ }^{2}$, H. Ørskov ${ }^{1}$ and W.Kiess ${ }^{2}$ \\ ${ }^{1}$ Institute of Experimental Clinical Research, University of Aarhus, Aarhus Kommunehospital, Aarhus, Denmark, and \\ ${ }^{2}$ Department of Paediatric Endocrinology, Laboratory of Cell Biology, Childrens Hospital, University of Munich, Munich, FRG
}

Summary. The insulin-like growth factors, insulin-like growth factor I and insulin-like growth factor II are bound to six distinct classes of insulin-like growth factor binding proteins (IGFBPs) in the circulation and in extracellular fluids. Diabetic renal hypertrophy is preceded by a transient increase in kidney insulin-like growth factor I suggestive of a renotropic function for insulin-like growth factor I. In order to examine a possible involvement of IGFBPs in initial diabetic kidney growth and in kidney insulin-like growth factor I accumulation; we studied rat kidney IGFBPs by ligand blotting during the first 4 days after induction of diabetes. Six distinct bands were identified in kidney and liver tissue with apparent molecular weight values of 38-47 (doublet), 34, 30, 24 and $20 \mathrm{kDa}$. The $38-47 \mathrm{kDa}$ doublet band probably corresponds to the insulin-like growth factor binding subunit of IGFBP-3, the $24 \mathrm{kDa}$ band to IGFBP-4 and the $30 \mathrm{kDa}$ band to IGFBP-1 and/or IGFBP-2, as these IGFBPs in rats have similar molecular weight. In untreated diabetic rats a transient increase in the kidney $30 \mathrm{kDa}$ band was demonstrable $24 \mathrm{~h}$ after induction of diabetes with a maximal rise (two- fold) after $48 \mathrm{~h}$, followed by a decrease to baseline values after 4 days. In untreated diabetic rats the $38-47 \mathrm{kDa}$ doublet band also increased (two-fold) in kidney during the first 2 days after induction of diabetes, followed by a subsequent decrease. Insulin-treatment prevented both the increase in the $30 \mathrm{kDa}$ and in the $38-47 \mathrm{kDa}$ bands. Kidney weight in untreated diabetic rats increased by $26 \%$ after 4 days. In conclusion, the present study shows a transient increase in the $30 \mathrm{kDa}$ and the $38-47 \mathrm{kDa}$ IGFBP species in hypertrophying diabetic kidneys, contemporarily with the previously described transient increase in extractable kidney insulin-like growth factor I content. These findings support the concept that IGFBPs may be involved in the action of insulin-like growth factor I and possibly in the diabetic kidney insulin-like growth factor I accumulation.

Key words: Kidney, hypertrophy, insulin-like growth factors, insulin-like growth factor binding proteins, streptozotocin, diabetes, rat.
The insulin-like growth factors, IGF-I and IGF-II are bound to specific IGF binding proteins (IGFBPs) in the circulation and in extracellular fluids. Six different IGFBPs have been characterized and designated IGFBP-1 to -6 [1]. Human (h) IGFBP-1 and hIGFBP-2 are $28 \mathrm{kDa}$ and $31 \mathrm{kDa}$ proteins, while rat (r) IGFBP-1 has a molecular weight similar to rIGFBP-2 (29 kDa) [1]. IGFBP-1 and -2 are primarily regulated by insulin [1] and largely growth hormone $(\mathrm{GH})$-independent $[1]$, while IGFBP-3 is GH-dependent and the predominant carrier of IGFs in the circulation [1]. IGFBP-3 is composed of two parts forming a $150 \mathrm{kDa}$ complex: an IGF binding, acid-stable glycoprotein which on gel electrophoresis appears as a major and minor band, corresponding to molecular weight 47 and $38 \mathrm{kDa}$ [1] and an acid-labile, nonIGF-binding subunit with a molecular weight of $84-86 \mathrm{kDa}$. The IGFBP-4, -5 and -6 have only recently been characterized and little is known about their tissue distribution and function [1].

IGFBPs may play an important role as local modulators of IGF actions. Such mechanisms could especially be operative for IGFBP-1 and -2, since these binding proteins contain an Arg-Gly-Asp tripeptide, which implies that they may interact with cell surfaces [2]. Induction of streptozotocin (STZ)-diabetes mellitus causes a dramatic increase in hepatic mRNA IGFBP-1 and -2 levels, and circulating IGFBP-1 levels show a four-fold increase 2 to 3 days after induction of diabetes [3-5]. A renotropic function for IGF-I has been proposed in diabetic kidney growth [6]. The rapid renal hypertrophy becomes significant $48-72 \mathrm{~h}$ following induction of diabetes and is preceded by a transient rise in renal IGF-I concentration, reaching a peak after $24-48 \mathrm{~h}$ and returning to basal levels after about 4 days [6]. 
In order to assess a possible involvement of IGFBPs in the kidney IGF-I accumulation and initial diabetic renal growth, we measured rat kidney IGFBPs by ligand blotting during the first 4 days after induction of STZdiabetes.

\section{Materials and methods}

\section{Animals}

Male Wistar rats (Møllegaards Avlslab., Eiby, Denmark) with a mean body weight of $213 \mathrm{~g}$ ( $7-8$ weeks of age) were studied. Rats were housed three per cage in a room with $12: 12 \mathrm{~h}(06.00$ 18.00 hours) artificial light cycle, temperature $21 \pm 2{ }^{\circ} \mathrm{C}$ and humidity $55 \pm 2 \%$. The animals had free access to standard rat chow (Altromin, Lage, FRG) and tap water throughout the experiment. The animals were randomized into three groups matched for body weight: (1) control animals $(n=6)$; (2) diabetic animals, no insulin treatment $(n=24)$ and (3) diabetic animals, insulin-treated $(n=24)$. Diabetes was induced at day 0 by i.v. injection of STZ $(55 \mathrm{mg} / \mathrm{kg}$ body weight) in acidic $0.154 \mathrm{~mol} / \mathrm{l} \mathrm{NaCl}(\mathrm{pH} 4.0)$ following $12 \mathrm{~h}$ of food deprivation. Eighteen hours after administration of STZ, and daily thereafter, the animals were weighed, urinalysis performed for glucose and ketones using Neostix 4 (Ames Limited, Stoke Poges, Slough, UK) and tail-vein blood glucose determined by Haemoglucotest 1-44 and Reflolux II reflectance meter (Boehringer-Mannheim, Mannheim, FRG). Insulin treatment with a very long-acting, heat-treated Ultralente Insulin (Novo-Nordisk, Bagsværd, Denmark) was initiated $18 \mathrm{~h}$ after administration of STZ when all animals had blood glucose levels above $20 \mathrm{mmol} / \mathrm{l}$. Insulin was given in an initial dose of 4-6 IU, followed by 1-3 IU daily thereafter depending on blood glucose values. On days 1,2,3 and 4, six animals from each of the two diabetic groups were studied in addition to six control animals on day 0 . Under sodium barbital anaesthesia ( $50 \mathrm{mg} / \mathrm{kg}$ body weight) blood was drawn from the retro-orbital venous plexus and serum stored at $-80^{\circ} \mathrm{C}$. The animals were rapidly dissected to obtain the kidneys and liver. The tissues were rapidly blotted, weighed and immediately frozen in liquid nitrogen and stored at $-80^{\circ} \mathrm{C}$ until analysis.

\section{Tissue extraction}

Approximately $20 \mathrm{mg}$ of thawed kidney or liver tissue was placed in $1.5 \mathrm{ml}$ polypropylene tubes and weighed. The tissue was homogenized for $2 \mathrm{~min}$ in $0.5 \mathrm{ml}$ of $20 \mathrm{mmol} / \mathrm{l}$ Tris, $2 \%$ Triton X-100 buffer (pH 7.4) using a micropestel (RPI catalog number 9922, Research Products International, Mount Prospect, Ill., USA). After adding $0.13 \mathrm{ml}$ of Laemmli buffer [7], each tube was boiled for $5 \mathrm{~min}$ and incubated overnight at $4^{\circ} \mathrm{C}$. Aliquots of extracts were stored at $-70^{\circ} \mathrm{C}$. Protein content of the extracts was measured using a protein assay (Pierce Rockford, Cat. no.23225, Rockford, Ill., USA) with bovine serum albumin as standard.

\section{SDS-PAGE and ligand blot analysis of IGFBPS}

SDS-PAGE and ligand blot analysis was performed according to the method of Hossenlopp et al. [7]. Three to four animals from each group on day $0,1,2,3$ and 4 were randomly selected for IGFBP analysis. Thawed extracts were boiled for $1 \mathrm{~min}$ and centrifuged for $1 \mathrm{~min}$ at $13,000 \mathrm{rev} / \mathrm{min}$. An aliquot of the supernatant equivalent to $200 \mu \mathrm{g}$ of protein or in a subset of experiments $2 \mu \mathrm{l}$ of serum, was subjected to SDS-PAGE (10\% polyacrylamide) under non-reducing conditions. The electrophoresed proteins were transferred by electroelution onto nitrocellulose paper (Schleicher \& Schuell, Munich, FRG) and the membranes were incubated overnight at $4^{\circ} \mathrm{C}$ with ap- proximately $500,000 \mathrm{cpm}^{125} \mathrm{I}-\mathrm{IGF}-\mathrm{II}$ (specific activity $2000 \mathrm{Ci} / \mathrm{mmol}$, Amersham International, Amersham, Bucks, UK) in $10 \mathrm{ml}$ $10 \mathrm{mmol} / 1$ Tris- $\mathrm{HCl}$ buffer (TBS) containing $1 \%$ bovine serum albumin and $0.1 \%$ Tween ( $\mathrm{pH} 7.4$ ). Membranes were washed with TBS and after drying overnight, the nitrocellulose sheets were autoradiographed with Kodak X-AR film and exposed to Du Pont-New England Nuclear enhancing screens at $-70^{\circ} \mathrm{C}$ for $3-7$ days. Specificity of the IGFBP bands was ensured by competitive co-incubation of ${ }^{125} \mathrm{I}$-IGF-II with unlabeled IGF-II $(1 \mu \mathrm{g} / \mathrm{ml})$ kindly donated by Lilly Research Lab. (Indianapolis, Ind., USA) or Kabi Peptides (Stockholm, Sweden).

\section{Densitometry}

Autoradiographs of ligand blots were scanned using a laser densitometer (Ultro Scan XL, LKB, Bromma, Sweden). The relative densities of the bands were measured as arbitrary absorbance units per milimeter.

\section{Statistical analysis}

Differences between groups were analysed using unpaired Student's $t$-test. When more than two groups were compared, one-way analysis of variance with the Bonferroni test for multiple comparisons and unpaired $t$-test was used. Results are given as mean values \pm SEM.

\section{Results}

\section{Metabolic parameters (Table 1) and body weight}

All animals given STZ developed hyperglycaemia within $18 \mathrm{~h}$ with blood glucose concentrations above $20 \mathrm{mmol} / \mathrm{l}$. Blood glucose concentrations in untreated diabetic animals stabilized at approximately $27 \mathrm{mmol} / 1$ after $24 \mathrm{~h}$ and remained at that level for the duration of the study. In insulin-treated animals blood glucose decreased to around

Table 1. Blood glucose and kidney weight in non-diabetic control rats on day 0 and in untreated and insulin-treated diabetic rats during the 4 days studied

\begin{tabular}{llllll}
\hline $\begin{array}{l}\text { Blood glucose } \\
(\mathrm{mmol} / \mathrm{l})\end{array}$ & Day 0 & Day 1 & Day 2 & Day 3 & Day 4 \\
\hline $\begin{array}{l}\text { Untreated } \\
\text { diabetic rats }\end{array}$ & & $27.3 \pm 1.0$ & $27.9 \pm 0.7$ & $29.0 \pm 0.7$ & $27.7 \pm 1.0$ \\
$\begin{array}{l}\text { Insulin-treated } \\
\text { diabetic rats }\end{array}$ & $5.1 \pm 0.6$ & $4.2 \pm 0.6$ & $4.0 \pm 0.5$ & $4.1 \pm 0.5$ \\
$\begin{array}{l}\text { Non-diabetic } \\
\text { control rats }\end{array}$ & $5.1 \pm 0.3$ & & & & \\
\hline $\begin{array}{l}\text { Kidney weight } \\
\text { (mg) }\end{array}$ & Day 0 & Day 1 & Day 2 & Day 3 & Day 4 \\
\hline $\begin{array}{l}\text { Untreated } \\
\text { diabetic rats }\end{array}$ & & $772 \pm 23^{\mathrm{a}}$ & $810 \pm 21^{\mathrm{b}}$ & $812 \pm 18^{\mathrm{b}}$ & $873 \pm 36^{\mathrm{b}}$ \\
$\begin{array}{l}\text { Insulin-treated } \\
\text { diabetic rats }\end{array}$ & $685 \pm 19$ & $710 \pm 17$ & $715 \pm 28$ & $693 \pm 25$
\end{tabular}

Non-diabetic

control rats $693 \pm 20$

${ }^{\mathrm{a}} p<0.05,{ }^{\mathrm{b}} p<0.01$ untreated rats vs insulin-treated diabetic rats. Values are given as mean \pm SEM. $n=6$ 


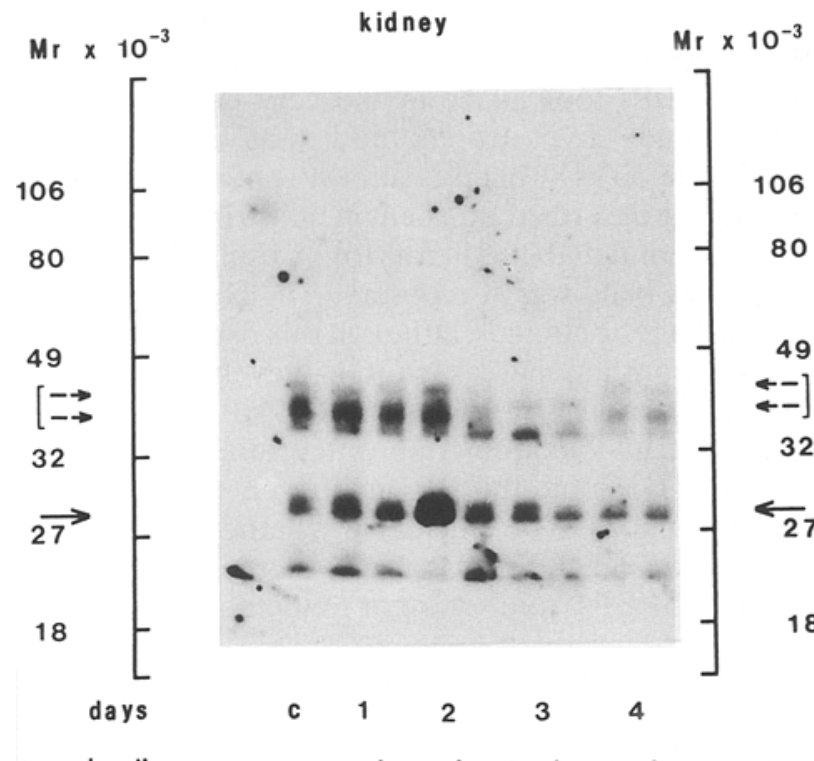

a insulin

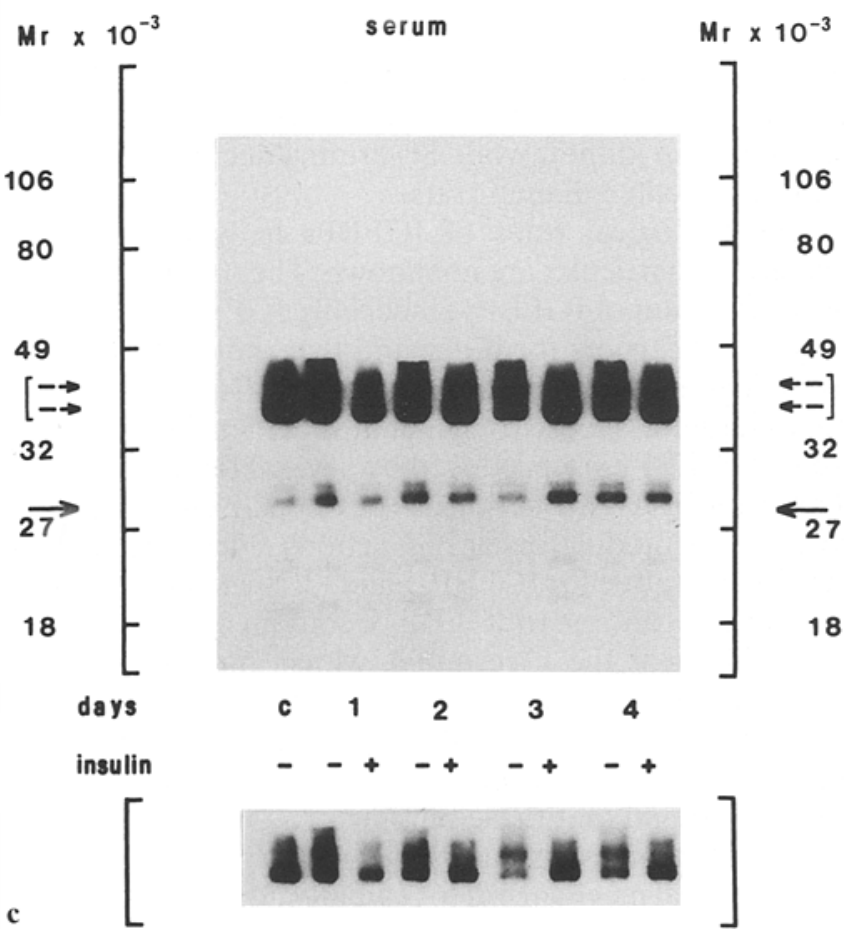

Fig.1 (a-c). ${ }^{125}$ I-insulin-like growth factor II ligand blot analysis of kidney $\mathbf{a}$, liver $\mathbf{b}$ and serum $\mathbf{c}$ insulin-like growth factor binding proteins (IGFBPs) in non-diabetic control (C), untreated diabetic (-) and insulin-treated diabetic $(+)$ animals during 4 days after induction of diabetes. Kidney, liver and serum IGFBPs were separated by SDS-PAGE (10\% gel), transferred to nitrocellulose sheets, and ligand blotting was performed as described in Materials and methods. In panel $\mathbf{c}$, a briefer exposure $(8 \mathrm{~h})$ of the same autoradiograph (upper panel) is also shown to demonstrate the pattern of IGFBP species in the $38-47 \mathrm{kDa}$ region. In all panels $[\rightrightarrows$ points to the $38-47 \mathrm{kDa}$ IGFBP species and $\rightarrow$ points to the main $30 \mathrm{kDa}$ IGFBP species

$5 \mathrm{mmol} / 16 \mathrm{~h}$ after the first injection and remained stable thereafter with values not different from non-diabetic control animals (Table 1). All untreated diabetic animals had glycosuria greater than $111 \mathrm{mmol} / \mathrm{l}$ and none of the animals exhibited ketonuria at any time during the study.

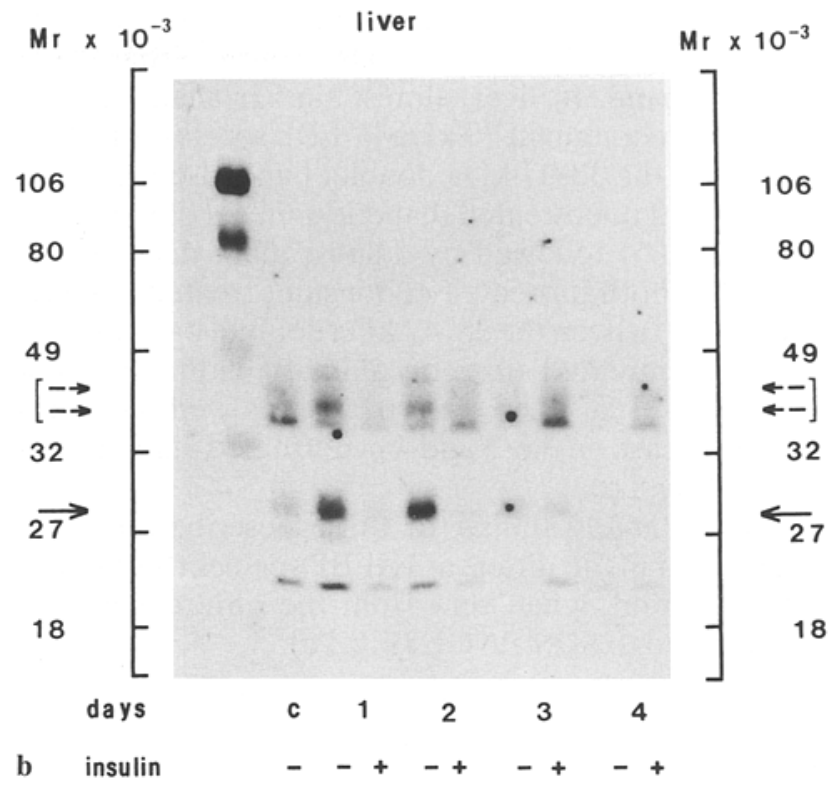

Untreated diabetic animals had a body weight loss of $6 \%$ on day $2(p<0.05)$, followed by an increase during the study approaching the initial body weight. Insulin-treated diabetic animals did not lose weight, and at day 4, the body weight of insulin-treated diabetic rats was $226 \pm 3 \mathrm{~g}$ $(n=6)$, significantly different from the body weight in untreated diabetic animals $(205 \pm 5 \mathrm{~g}, n=6)(p<0.01)$.

\section{Kidney weight (Table 1)}

A marked increase in kidney weight was observed in untreated diabetic animals, significantly different from insulin-treated diabetic animals as early as $24 \mathrm{~h}$ after induction of diabetes $(p<0.05)$ (Table 1). After 4 days of untreated diabetes, kidney weight had increased by $26 \%$ when compared to insulin-treated diabetic control rats $(p<0.01)$ (Table 1). Kidney weight in insulin-treated diabetic animals on day 4 was not significantly different from kidney weight in non-diabetic control rats on day 0 (Table 1).

\section{Ligand blots of kidney, liver and serum IGFBPs (Fig. 1)}

Autoradiographs of ligand blots of IGFBPs in kidney, liver and serum in untreated and insulin-treated diabetic rats on day 1,2,3 and 4 and in non-diabetic control rats on day 0 are shown in Figure 1. Ligand blots of kidney, liver and serum from non-diabetic control rats yielded six bands of IGFBPs with apparent molecular weights of $38-47 \mathrm{kDa}$ (doublet), 34, 30, 24 and $20 \mathrm{kDa}$. Binding of ${ }^{125}$ I-IGF-II to these binding species in ligand blotting experiments was specific, since co-incubation of radioligand with unlabelled IGF-II led to complete competitive inhibition of binding (data not shown). In kidney, induction of diabetes resulted in a transient elevation of the $30 \mathrm{kDa}$ band on day 1 , with a maximal rise on day $2(200 \pm 61 \%$, $n=3)(p<0.05)$ (Fig.1a). The elevation of the $30 \mathrm{kDa}$ 
band declined to baseline level on day 3 to 4 (Fig. 1 a). Insulin treatment in diabetic animals abolished the rise in the $30 \mathrm{kDa}$ band. In liver, almost similar changes were seen in the predominant $30 \mathrm{kDa}$ IGFBP species (Fig. $1 \mathrm{~b}$ ).

In kidney, the $38-47 \mathrm{kDa}$ doublet band also increased on day 1 and 2 in untreated diabetic animals ( $200 \pm 52 \%$, $n=3)(p<0.05)$ followed by a subsequent decrease on day 3 to 4 in both untreated and insulin-treated diabetic rats (Fig. $1 \mathrm{a}$ ). In liver, the $38-47 \mathrm{kDa}$ doublet band also increased in untreated diabetic animals within the first 2 days $(133 \pm 21 \%, n=3)(p<0.05)$, followed by a subsequent decrease on day 3 and 4 in untreated diabetic animals only (Fig. 1 b).

Changes, largely similar to those described in liver, were detected in the different IGFBP species throughout the study period, when sera from the different groups were subjected to SDS-PAGE (Fig. 1c).

\section{Discussion}

The IGFBPs are a family of structurally related proteins which form simple binary complexes with IGF-I and IGFII. Six distinct structural classes have been identified, designated IGFBP-1 to IGFBP-6 [1]. The relevance of examining possible changes in the renal IGFBP pattern in diabetic rats was determined by the previous finding that experimental diabetes is associated with a number of changes in circulating and hepatic levels of IGFBPs [3-5, 8]. Furthermore, a transient renal IGF-I accumulation occurs within the first 4 days after induction of experimental diabetes [6].

In the present study we used ${ }^{125}$ I-IGF-II ligand blotting to characterize IGFBPs by SDS-PAGE analysis. The use of IGFBP antibodies on SDS-PAGE in immunoblotting experiments would provide more specific information of the distinct classes of IGFBPs, but the scarcity of specific antibodies against rat IGFBPs and the variable cross-reactivity of human antibodies to rat IGFBPs necessitated the use of ligand blotting. ${ }^{125} \mathrm{I}-\mathrm{IGF}-\mathrm{II}$ ligand blotting in rat kidney and liver tissue yielded six bands of IGFBPs with apparent molecular weights of $38-47 \mathrm{kDa}$ (doublet), 34, $30,24 \mathrm{kDa}$ and $20 \mathrm{kDa}$. In accordance with previous observations the $38-47 \mathrm{kDa}$ doublet band may correspond to the acid-stable IGF binding subunit of IGFBP-3, the $24 \mathrm{kDa}$ band to IGFBP-4 and the $30 \mathrm{kDa}$ band may represent both IGFPB-1 and -2, as these IGFBPs in rats have similar molecular weight $[1,8]$.

Induction of STZ-diabetes causes a dramatic increase in hepatic mRNA levels of IGFBP-1 and IGFBP-2, with complete or partial normalization following insulin therapy $[3,5]$, suggesting that the main regulators of these two IGFBPs are insulin and/or blood glucose levels $[1,3,5]$. Furthermore, circulating IGFBP-1 levels exhibit a fourfold increase as early as 2 to 3 days after induction of diabetes [4]. In addition, circulating levels of IGFBP-3 are decreased in experimental diabetes in rats after a diabetes duration of 3 weeks [8].

In the present study we demonstrated a transient in crease in a $30 \mathrm{kDa}$ IGFBP band in hypertrophying kidneys from diabetic rats. The increased levels were totally abolished in kidneys from insulin-treated diabetic rats, as was the renal growth. It is noteworthy that the rise in the $30 \mathrm{kDa}$ IGFBPs took place in the very early stages of diabetic kidney hypertrophy and that the temporal change in the $30 \mathrm{kDa}$ band is almost superimposible on the previously described transient increase in kidney IGFI in experimental diabetes in rats [6]. A transient increase in the $30 \mathrm{kDa}$ band was also observed in liver tissue from untreated diabetic animals, although this rise is not associated with a transient increase in IGF-I levels in this organ [6]. These differences in IGF-I and IGFBP levels in kidney and liver may demonstrate differential and flexible regulation of IGFs and IGFBPs in different tissues. In this context, it remains to be elucidated whether the increase in kidney and liver IGFBPs is due to increased uptake of circulating IGFBPs from serum or to increased local production.

Circulating levels of IGFBP-3 are low in experimental diabetes in rats after a diabetes duration of 3 weeks [8]. In the present study the 38-47 kDa doublet band was elevated in both kidney, liver and serum during the first 2 days after induction of diabetes, despite the fact that $\mathrm{GH}$ secretion is gradually decreasing within this period. This increase was followed by a subsequent decrease on day 4 in all animals in kidney, while in serum a decrease was seen only in untreated diabetic rats.

The biological roles of IGFBPs in general and in diabetes in particular are not known. The original concept of the function of IGFBPs (especially IGFBP-3) was that they act as carriers for IGFs, and that they protect IGFs from degradation, thereby ensuring a sufficient IGF supply to target tissues. Now, when it is evident that IGFs as well as IGFBPs are produced by several tissues, another dimension of IGFBP action has developed, emphasizing a role as local modulators of IGF actions. Such mechanisms may be operative for IGFBP-1 and -2, since these binding proteins, in contrast to IGFBP-3, contain a Arg-Gly-Asp tripeptide near the C-terminal, which implies that they could interact with cell surfaces and thus deliver IGF to adjacent IGF receptors, enhancing the subsequent binding and actions of IGF-I on cells [2]. Other workers have, however, found that these binding proteins inhibit IGF-I binding to some cell types [9], raising the possibility of differential local mechanisms to regulate individual tissue responsiveness to IGF-I. Finally, Busby et al. [10] reported that one form of IGFBP-1 can form multimers through disulphide linkage and thus preferentially adhere to extracellular matrices and cell surfaces. Future research in this field should be directed at elucidating the mechanisms underlying the changes in kidney and liver IGFBPs in diabetes, and searching for different growth properties of the IGFBPs.

In conclusion, the present study shows a transient increase in the $30 \mathrm{kDa}$ and in the $38-47 \mathrm{kDa}$ IGFBP species in hypertrophying diabetic rat kidneys. Due to molecular weight similarity between rIGFBP-1 and rIGFBP-2 the rise in this $30 \mathrm{kDa}$ band may reflect a rise in either or both of these IGFBPs. It is interesting that the transient accumulation in kidney IGFBPs occurs simultaneously with the previously described transient increase in extractable kidney IGF-I in diabetic animals. This temporal relation- 
ship supports the notion that IGFBPs may be involved in the renotropic action of IGF-I in diabetic kidney hypertrophy.

Acknowledgements. This study was supported by grants from the Danish Diabetes Association, the Danish Medical Research Council, the Ruth König Petersen Foundation, the Novo Foundation, the Nordic Insulin Foundation, the Aage Louis-Hansen Memorial Foundation and the Deutsche Forschungsgemeinschaft, Bonn (grants $\mathrm{Ki} 365 / 1.1$ and $\mathrm{Ki} 365 / 1.2$ ). We would like to thank Lilly Research Lab., Indianapolis, Indiana, USA, and Dr. A.Skottner, Kabi Peptides, Stockholm, Sweden for their generous gifts of recombinant human IGF-II.

\section{References}

1. Drop SLS, Brinkman A, Kortleve DJ, Groffen CAH, Schuller A, Zwarthoff EC (1991) The evolution of the insulin-like growth factor binding family. In: Spencer EM (ed) Modern concepts of insulin-like growth factors. Elsevier, New York, pp 311-328

2. De Vroede MA, Tseng LY, Katsoyannis PG, Nissley SP, Rechler MM (1986) Modulation of insulin-like growth factor I binding to human fibroblast monolayer cultures by insulin-like growth factor carrier proteins released to the incubation media. J Clin Invest 77: 602-613

3. Ooi GT (1990) Insulin-like growth factor-binding proteins (IGFBPs): more than just 1,2,3. Mol Cell Endocrinol 71: C39C43

4. Unterman TG, Oehler DT, Becker RE (1989) Identification of a Type 1 insulin-like growth factor binding protein (IGFBP) in serum from rats with diabetes mellitus. Biochem Biophys Res Commun 163: 882-887
5. Böni-Schnetzler M, Binz K, Mary JL, Schmid C, Schwander J, Froesch ER (1989) Regulation of hepatic expression of IGF-I and fetal IGF binding protein mRNA in streptozotocin-diabetic rats. FEBS Lett 251:253-256

6. Flyvbjerg A, Bornfeldt KE, Marshall SM, Arnquist HJ, Ørskov $H(1990)$ Kidney IGF-I mRNA in initial renal hypertrophy in experimental diabetes in rats. Diabetologia 33:334-338

7. Hossenlopp P, Seurin D, Segovia-Quinson B, Hardouin S, Binoux M (1986) Analysis of serum insulin-like growth factor binding proteins using Western blotting: use of the method for titration of the binding proteins and competitive binding studies. Anal Biochem 154: 138-143

8. Zapf J, Hauri C, Waldvogel M et al. (1989) Recombinant human insulin-like growth factor I induces its own specific carrier protein in hypophysectomized and diabetic rats. Proc Natl Acad Sci USA $86: 3813-3817$

9. Ritvos O, Ranta T, Jalkanen J (1988) Insulin-like growth factor (IGF) binding protein from human decidua inhibits the binding and biological action of IGF-I in cultured choriocarcinoma cells. Endocrinology 122: 2150-2157

10. Busby WH Jr, Klapper DG, Clemmons DR (1988) Purification of a 31,000-dalton insulin-like growth factor binding protein from human amniotic fluid. J Biol Chem 263: 14203-14210

Received: 5 December 1991

and in revised form: 15 January 1992

Dr. A. Flyvbjerg

Institute of Experimental Clinical Research

Aarhus Kommunehospital

DK-8000 Aarhus C

Denmark 